\title{
Osler-Weber-Rendu syndrome
}

\author{
Ghobad Abangah, ${ }^{1}$ Milad Rashidbeygi ${ }^{2}$
}

1Shahid Mustafa Hospital, Ilam University of Medical Sciences, Ilam, Iran

${ }^{2}$ Student Research Committee, Ilam University of Medical

Sciences, Ilam, Iran

\section{Correspondence to} Dr Milad Rashidbeygi, miladrashidbeygi@yahoo.com

\section{DESCRIPTION}

A 57-year-old woman presented to the emergency department reporting of fresh rectal bleeding since 3 days ago. She had a history of spontaneous recurrent epistaxis since childhood but had never been fully evaluated. Her family history was also notable for a son with recurrent spontaneous epistaxis. Physical examination revealed telangiectasia of the tongue (figure 1) and fingertips (figure 2). Laboratory findings were compatible with severe iron deficiency anaemia. Lower gastrointestinal endoscopy showed arteriovenous malformation and telangiectasia in the colon (figures 3 and 4).With a history of spontaneous and recurrent epistaxis, multiple mucocutaneous telangiectasias, positive family history and gastrointestinal arteriovenous malformation and telangiectasia a clinical diagnosis of hereditary haemorrhagic telangiectasia (Osler-Weber-Rendu syndrome) was made. Radiological evaluation revealed no vascular malformation in other viscera.

Hereditary haemorrhagic telangiectasia (HHT) is an uncommon autosomal dominant disease that occurs on mucocutaneous surfaces (ie, nose, gastrointestinal tract and skin), lung, liver and brain. ${ }^{1}$ The Curaçao criteria was developed for the

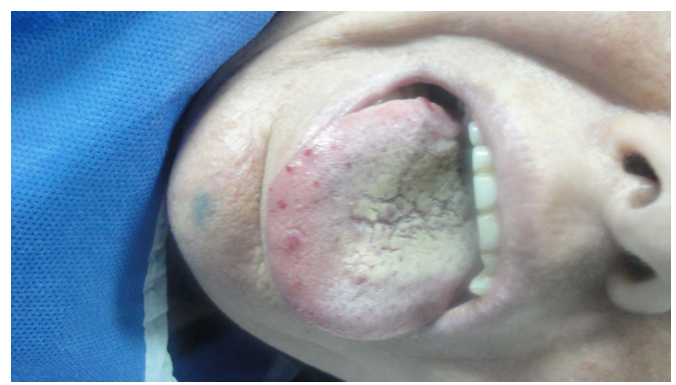

Figure 1 The telangiectasia of the tongue.

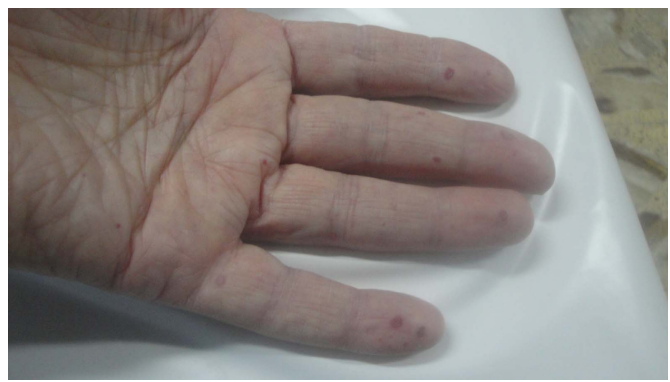

Figure 2 The telangiectasia of the fingertips.

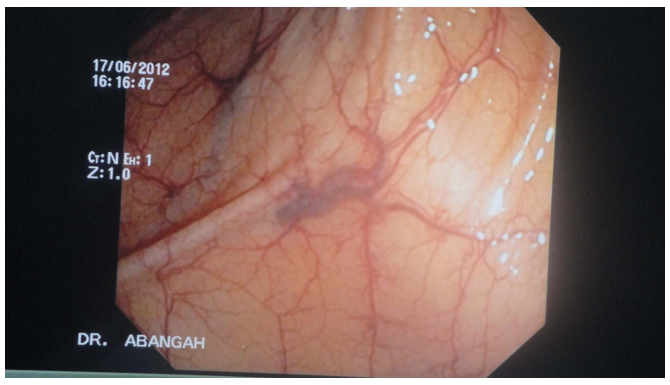

Figure 3 The arteriovenous malformation and telangiectasia in the colon.

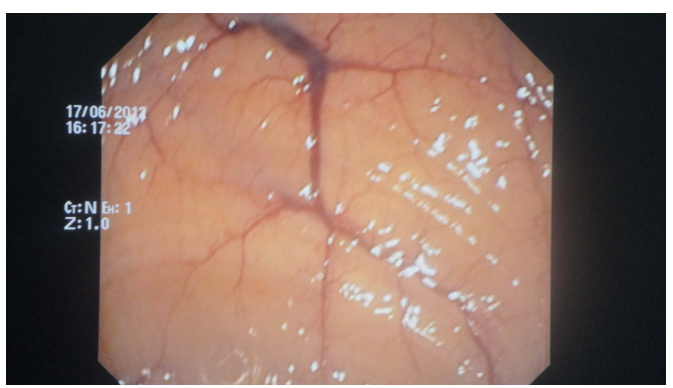

Figure 4 The arteriovenous malformation and telangiectasia in the colon.

diagnosis of HHT that contains epistaxis, family history, telangiectasias and visceral lesions. ${ }^{2}$

We were showed key recommendations with comments according to the Olitsky study for treatment of patient with $\mathrm{HHT}^{3}$ (Appendix).

Contributors The case was managed by GA and MR and read and approved the final manuscript. MR followed up the patient. MR and GA have.

\section{Competing interests None.}

Patient consent Obtained.

Provenance and peer review Not commissioned; externally peer reviewed.

\section{REFERENCES}

1 Trembath RC, Thomson JR, Machado RD, et al. Clinical and molecular genetic features of pulmonary hypertension in patients with hereditary hemorrhagic telangiectasia. N Engl I Med 2001;345:325-34.

2 Shovlin CL, Guttmacher AE, Buscarini E, et al. Diagnostic criteria for hereditary hemorrhagic telangiectasia (Rendu-Osler-Weber syndrome). Am J Med Genet 2000;91:66-7.

3 Olitsky SE. Hereditary hemorrhagic telangiectasia: diagnosis and management. Am Fam Physician 2010;82:785-90.
To cite: Abangah G,
Rashidbeygi M. BMJ Case Rep Published online:

[please include Day Month Year] doi:10.1136/bcr-2013201034 
Copyright 2013 BMJ Publishing Group. All rights reserved. For permission to reuse any of this content visit http://group.bmj.com/group/rights-licensing/permissions.

BMJ Case Report Fellows may re-use this article for personal use and teaching without any further permission.

Become a Fellow of BMJ Case Reports today and you can:

- Submit as many cases as you like

- Enjoy fast sympathetic peer review and rapid publication of accepted articles

- Access all the published articles

- Re-use any of the published material for personal use and teaching without further permission

For information on Institutional Fellowships contact consortiasales@bmjgroup.com

Visit casereports.bmj.com for more articles like this and to become a Fellow 